\title{
Introduction
}

\section{Freedom of Religion and Belief in the United Kingdom}

The United Kingdom (UK) is at a crossroads. The year 2018 commemorates twenty years since the onset of the Human Rights Act, transposing virtually literally the European Convention on Human Right into applicable and enforceable law of the Kingdom. At the same time, it is now a little over 5 years since the Brighton Declaration was adopted under the auspices of the British chairmanship of the Committee of Ministers of the Council of Europe-a Declaration which has sought to bring long overdue, necessary reforms to the previously rather jammed procedural side of the European Convention system, but a Declaration, at the same time, which may be construed as a political move to restrain the "meddling" European Court of Human Rights. A coalition of states led by the U K urged to European Court of Human Rights to heed such notions as subsidiarity, margin of appreciation, in sum: not to act as judicialactivist. The year 2018, furthermore, fine-tunes the divorce settlement between the $\mathrm{UK}$ and the European Union (EU).

It is against this turbulent backdrop that this special issue raises the question as to the state of religious freedom anno 2018. Have twenty years of HRA brought universal freedom of religion or belief to Britain? And what could be the effect on this freedom of the Brexit? Within this vast topic, choices need to be made. Topicality and urgency have informed the selection. The contributions in this issue deal with the questions of religious schools, the employment status of ministers of religion, experiences of British Muslim women, and religious minorities.

The autonomy and treatment of religious schools, Myriam Hunter-Henin debates and critiques in her contribution, is being renegotiated in the legalpolitical arena of the UK. Notably, state control of religious schools is on the rise. She examines to what extent this control restricts parents' right to send 
their children to schools in accordance with their beliefs and ultimately proposes a reinterpretation of the principle of religious autonomy.

Russell Sandberg examines the benefits of a concept of a "judicial retcon" through a detailed case study, exploring the uk case law regarding the question of whether ministers of religion are employees. Engaging with contemporary conflicts between the autonomy of religious groups and individual "secular" legal rights, he determines the usefulness of this tool-retroactive continuity-derived from literary criticism for legal scholarship.

The situation of Muslim women living in pluralistic European societies such as the UK is empirically studied by Sariya Cheruvallil-Contractor, especially concerning their human rights and freedoms. Through qualitative fieldwork, and interviews with British Muslims, she reveals processes of "othering" Islam and Muslims, and the experienced effects thereof on British Muslims.

Paul Weller, lastly, debates the situation of religious minorities in the UK on issues of religious freedom through a socio-legal study of census data. He establishes that key drivers in relevant changes to religious minority- and religious freedom policies in the last two centuries were various religious minorities themselves. In arguing that this process of "preconfiguration" and effects on social policy continues into the 21st century, he ultimately seeks to discern some of the ramifications of these processes in the "Post-Brexit Future".

\section{Özgür Heval Çınar}

Guest Editor; Principal Lecturer, BPP University, London, UK

\section{Jeroen Temperman}

Editor-in-Chief, Religion and Human Rights 